\title{
Stripped Down Like a Runner or Enriched by Experience: Bias and Impartiality of Judges and Jurors
}

\section{Citation}

Martha Minow, Stripped Down Like a Runner or Enriched by Experience: Bias and Impartiality of Judges and Jurors, 33 Wm. \& Mary L. Rev. 1201 (1992).

\section{Published Version}

http://scholarship.law.wm.edu/wmlr/vol33/iss4/5/

\section{Permanent link}

http://nrs.harvard.edu/urn-3:HUL.InstRepos:12933380

\section{Terms of Use}

This article was downloaded from Harvard University's DASH repository, and is made available under the terms and conditions applicable to Other Posted Material, as set forth at http:// nrs.harvard.edu/urn-3:HUL.InstRepos:dash.current.terms-of-use\#LAA

\section{Share Your Story}

The Harvard community has made this article openly available. Please share how this access benefits you. Submit a story.

Accessibility 


\section{William \& Mary Law Review}

\section{Stripped Down Like a Runner or Enriched by Experience: Bias and Impartiality of Judges and Jurors}

Martha Minow

Repository Citation

Martha Minow, Stripped Down Like a Runner or Enriched by Experience: Bias and Impartiality of Judges and Jurors, 33 Wm. \& Mary L. Rev. 1201 (1992), http://scholarship.law.wm.edu/wmlr/vol33/ iss $4 / 5$

Copyright c 1992 by the authors. This article is brought to you by the William \& Mary Law School Scholarship Repository. 

EXPERIENCE: BIAS AND IMPARTIALITY OF JUDGES AND JURORS

\section{Martha Minow*}

In phase one of the Senate Judiciary Committee hearings on the nomination of Clarence Thomas to serve as Associate Justice of the United States Supreme Court, Thomas testified that as a judge, " "You want to be stripped down like a runner," and "shed the baggage of ideology." "1 One observer commented that Thomas "painted a vivid image of a man methodically ridding himself not only of old ideas and even the desire to form new ones, but also of traits and attitudes that have formed the essence of his adult personality." 2 At the same time, his supporters argued that a man "who has experienced and overcome poverty and racial discrimination in his own life brings an important and perhaps irreplaceable perspective to the court." 3 Beginning with his opening presentation, Thomas presented himself as someone unburdened by a political perspective, yet enriched by his experiences of poverty and racial discrimination and therefore attentive to the concerns of disadvantaged people. ${ }^{4}$

After the second phase of committee hearings following the leak of Anita Hill's charges that Thomas sexually harassed her-

* Professor of Law, Harvard University. A.B., University of Michigan, 1975; M. Ed. Harvard University, 1976; J.D., Yale Law School, 1979. A version of this Essay was delivered as the James Gould Cutler Lecture at the Marshall-Wythe School of Law at the College of William and Mary on October 21, 1991. A further discussion of related issues appears in Martha Minow, Equalities, $88 \mathrm{~J}$. PHIL. 633 (1991). The author would like to thank Betsy Fishman, Marjorie Sheldon, and the editors of the William and Mary Law Review for their fine assistance. Thanks also to Joe Singer, Elena Kagan, Frank Michelman, Avi Soifer, and Elizabeth V. Spelman.

1. Linda Greenhouse, The Thomas Hearings: In Trying to Clarify What He Is Not, Thomas Opens Question of What He Is, N.Y. Trmes, Sept. 13, 1991, at A19 (quoting Judge Clarence Thomas). At another point, responding to a question from Senator Dennis DeConcini, Thomas said,

I think it's important for judges not to have... baggage. I think... it is important for us ... to eliminate agendas, to eliminate ideologies. And when one becomes a judge... you start putting the speeches away. You start putting the policy statements away. You begin to decline forming opinions in important areas that could come before your court because you want to be stripped down like a runner.

David Broder, Thomas Backs Democrats into a Corner, CHI. TRIB., Sept. 15, 1991, at 3.

2. Greenhouse, supra note 1, at A19.

3. Broder, supra note 1 , at 3.

4. Greenhouse, supra note 1 , at A19. 
the portion that Thomas called a "high-tech lynching"5-the tension over perspective and impartiality only became compounded. Thomas explained that he had come to better and personally understand the need for rights for the accused. ${ }^{6} \mathrm{He}$ emphasized his own right to privacy and demonstrated deep concern about the operation of racial stereotypes. ${ }^{7}$ Yet he also attacked liberal interest groups and the press, as well as the Senate itself, for staging the high-tech lynching. He conveyed his disrespect for everyone responsible for the process.

Do these experiences render him less, or more, qualified for the position he now serves on the United States Supreme Court? Will he be able to strip himself of his anger toward the Senate when he reviews questions of congressional intent? Will he be able to assure litigants of his impartiality in sexual harassment cases, in cases involving freedom of the press, or in cases addressing senatorial decisions?

These questions expose intense confusion about bias, impartiality, knowledge, and experience. This confusion permeates contemporary American legal thought, especially concerning the selection of judges and juries. The confusion is particularly pronounced because the ultimate goal of fairness in our society includes notions of representation as well as ideas of neutrality. The jury is to reflect a fair cross-section of the community. ${ }^{8}$ Yet the very existence of peremptory challenges, which give litigants the power to strike a certain number of participants from the jury without having to state any reason, ${ }^{9}$ creates tension with the goal of a cross-section in the very process of permitting the parties some modicum of control over what they perceive to be fair or advantageous at trial. The Supreme Court has ruled that peremptory challenges affecting the composition of both civil and criminal juries must not intentionally exclude participants on the basis of race or gender so as to undermine the goal of a fair cross-section of the community..$^{10}$

5. 137 Cong. Rec. S14,632 (daily ed. Oct. 15, 1991) (statement of Sen. Byrd).

6. See Richard L. Berke, The Thomas Nominations: Thomas Backers Attack Hill, N.Y. Times, Oct. 13, 1991, at 1.

7. Id.

8. See Taylor v. Louisiana, 419 U.S. 522, 526 (1975) (noting that the American concept of jury trial contemplates jury drawn from cross-section of community); Hernandez v. Texas, 347 U.S. 475, 482 (1954) (holding that conviction by unrepresentative jury violates equal protection). Even judicial elections, as the Supreme Court ruled last year, are governed by the Voting Rights Act. Chisom v. Roemer, 111 S. Ct. 2354 (1991).

9. Swain v. Alabama, 380 U.S. 202, 220 (1965).

10. See, e.g., Holland v. Illinois, 493 U.S. 474 (1990); Batson v. Kentucky, 476 U.S. 79 (1986). Challenges for cause more directly address the issue of bias. I focus here on the use of peremptory challenges rather than challenges for cause in the shaping of juries. 
My goal in this Essay is to consider three contrasting views of bias and their relationships to the ideal of fair representation in the selection of juries and judges. As a nation, we seem to want those who sit in judgment to have no axes to grind, no prejudgments about the people or issues they confront. We also want them to have the ability to empathize with others, to evaluate credibility, to know what is fair in this world, not in a laboratory. And we want jurors and judges to have, and to remember, experiences that enable their empathy and evaluative judgments. This ambivalence, I will suggest, reflects a misunderstanding of the preconditions for impartiality and of the role of fair representation in producing impartial jurors and panels of judges. Common sense, case law, fiction, and even movies illuminate these questions.

\section{Do We Know Bias When We See It?}

First, let me ask whether we know bias when we see it. Consider the cartoon depicting a judge with a large nose and mustache, looking down from the bench at a defendant with the same nose and mustache. The judge declares: "Obviously, not guilty." 11 This cartoon illustrates the usual meaning of bias. It refers to an inclination, a predilection, that interferes with impartiality. A potential juror poses the danger of bias when he or she is too close to the parties or the issue at hand. By knowing the people involved, by having a direct stake in the proceeding, or by having had a very similar kind of experience as the one under scrutiny, the potential juror may lack or appear to lack the distance necessary to judge fairly.

Normally, we think that a person is or appears to be biased toward friends, family members, or business associates. This view reflects a sharp departure from the early conception of a jury as a group of people from a community who knew the parties and who could serve as witnesses to give evidence about the dispute. ${ }^{12}$ It is one of those curious historical transformations-much like the transformation of the term "jury of one's peers" from a reference to nobles to a reference to random cross-sections of society. The jury for Oliver North excluded anyone who had

11. Charles Barsotti, New YORKer, Nov. 21, 1988, at 55.

12. VALERIE P. HANS \& NeIl VIDMAR, JudGING THE JuRY 23-24 (1986). 
followed or even heard about his testimony in the congressional Iran-Contra hearings. ${ }^{13}$ The jury included thus only members of that odd group of people who were able to sequester themselves from a major topic of broad public interest and discussion.

To be fair, this notion of removal reflects the desire to guard against prejudice-to avoid those who prejudge the issues at hand. A juror who has been exposed to pretrial publicity might have or seem to have a view about the merits of the case or the virtues and vices of one or more parties. The question remains, however: how is bias to be tested? A majority of the Supreme Court has recently ruled that the issue of bias in the face of pretrial publicity is avoided when the jurors report to the court that they think they can be fair. ${ }^{14}$ The jurors' subjective reflections may be one component of any proper impartiality inquiry, but I wonder whether this is sufficient. A juror may not fully understand either the meaning or the demands of impartiality; the juror may miscalculate his or her ability to put aside knowledge that could prejudice judgment. In addition, the simple appearance of bias may damage the basic commitment to a fair trial process.

Variations on such questions of evidence and proof abound. For example, who has the burden of showing that a prospective juror is actually prejudiced? In a homicide case, one juror attended church with the mother of the decedent but was nonetheless allowed to serve on the jury. ${ }^{15} \mathrm{~A}$ Supreme Court majority refused to grant certiorari in the case despite Justice Marshall's dissenting view that the defendant ought not to bear the burden of showing actual prejudice when the probability of bias was so great. ${ }^{16}$

Aside from such questions of proof, the first notion of bias begins to emerge with some clarity. A juror may be or may seem biased because of personal experience with the parties or exposure to publicity about their conduct. That juror seems too close to the matter at hand to render a fair and objective judgment.

Does this mean that no bias arises if the juror is in the opposite situation? What if the juror is extremely far from the matter at

13. North Jury Selection Bogs Down: Public Familiarity with Him Poses Problem, Judge Says, L.A. Trmes, Jan. 31, 1989, at 1.

Thomas felt compelled to state that he had never discussed Roe v. Wade, 410 U.S. 113 (1973), with anyone. See The Thomas Hearings: Excerpts from Senate's Hearings on the Thomas Nomination, N.Y. Trmes, Sept. 12, 1991, at A20.

14. Mu'Min v. Virginia, 111 S. Ct. 1899, 1908 (1991).

15. Porter v. Illinois, 479 U.S. 898 (1986).

16. Id. at 901 (Marshall, J., dissenting from denial of certiorari). 
hand in either personal experience or knowledge? Professor Lon Fuller once discussed the danger that jurors called to judge a sailor charged with threatening another with bodily harm would not understand the mores of the waterfront and would attribute too much to testimony that the defendant had said in the past that he would "'stick a knife in [someone's] guts and turn it around three times." "17 Is it possible to risk actual bias, or its appearance, by having a total absence of experience or knowledge of the issue or evidence at hand? To be able to evaluate statements of witnesses, a jury needs sufficient knowledge of the witnesses' worlds to place their statements in context. Moreover, to be able to render judgment, jurors need sufficient knowledge of the life experiences of those before them to make sense of testimony and motivations. Even when women were excluded from jury service, for example, Anglo-American tradition provided for the use of midwife juries on occasions in which knowledge of pregnancy or childbirth would be critical to a reliable judgment. ${ }^{18}$ Perhaps that practice also reflected some delicacy of feeling about whose ears should hear such intimate female matters; perhaps the practice embodied a notion of expertise rather than impartiality. ${ }^{19}$

Certainly arguments for the inclusion of women and AfricanAmericans on juries have long encompassed the view that female and African-American litigants deserved the chance to be evaluated by those with shared experiences. ${ }^{20}$ Some commonality is necessary to know enough to judge. Admittedly, this argument blends into the notion of a fair cross-section of the community regarded as an independently important concern about the jury. Both the appearance of fairness and the fact of equality in the jury selection process matter even apart from issues about what knowledge is necessary to judge fairly. But the Supreme Court has acknowledged that impartiality is served by juries that

17. Lon L. Fuller, The Forms and Limits of Adjudication, 92 HARv. L. REv. 353, 391 (1978).

18. See Lloyd E. Moore, The Jury: Tool of Kings, Paldadium of Liberty 128-29 (2d ed. 1988).

19. Cf. Judith Resnik, On the Bias: Feminist Reconsiderations of the Aspirations for Our Judges, 61 S. CAL. L. REv. 1877, 1912 n.121 (1988) (proferring differences between male and female judgments as explanation of exclusion and inclusion of women on juries).

20. See Douglas Colbert, Challenging the Challenge: Thirteenth Amendment as a Prohibition Against the Racial Use of Peremptory Challenges, 76 CoRnelu L. REv. 1, 6 (1990); Carol Weisbrod, Images of the Woman Juror, 9 HARv. WoMEN's L.J. 59, 80 (1986). 
represent a fair cross-section of the larger society. ${ }^{21}$ Although the distribution of knowledge and experience may not be equal, the collective deliberation process by a jury that is a fair crosssection will temper the dangers of ignorance. ${ }^{22}$

A confluence of the goals of fair representation and impartiality thus exists. Both include a basic idea about the distribution of experiences necessary to render fair judgments. The Clarence Thomas of September who sought to establish his impartiality, therefore, announced that he would retain his experiences of poverty and racial discrimination and his " underlying concerns and feelings about people being left out, about our society not addressing all the problems of people.'"23 Only a year earlier, David Souter had felt the need to convey to the Senate and to the watching public that despite a life as a bachelor and loner, he had women friends ${ }^{24}$ and that once as a college adviser he had even counseled a young woman who contemplated an abortion. ${ }^{25}$ Experience and familiarity with human emotions bring a judge or juror within the circle of people entitled and equipped to judge others. More particularly, both Thomas and Souter sought to establish that they had experiences with points of view not well represented at the high court. This reflects an admission that the Court's impartiality is threatened if it appears, because of its own narrow membership, to lack an understanding of the broad range of people who come before it.

A third kind of bias remains. It is perhaps the most elusive to state, and it also may be controversial to discuss. I want to explore it because I myself am suspicious of dualities. I am troubled by the suggestion that bias may arise when one is too close to but not when one is too far from a problem; but I am equally troubled by the idea that these two are the only dimensions that matter. Let us consider another dimension. Although

21. See Holland v. Mlinois, 493 U.S. $474,480-81$ (1990). But see id. at 495 (Marshall, J., dissenting) (arguing that the fair cross-section requirement serves purposes different from impartiality).

22. This goal may be jeopardized by extremely long trials, because a cross-section of the population is unlikely to be able to disengage from other commitments to serve on a jury for such a trial. For this reason, among others, some have proposed breaking long trials into smaller parts that can be heard by different panels, as Judge Robert Keeton has suggested to me in conversation.

23. Greenhouse, supra note 1 , at A19 (quoting Judge Clarence Thomas).

24. See, e.g., Alan McConagha, Souter's First Love: His Work, Wash. TmES, July 26, 1990 , at A6.

25. Ruth Marcus \& Michael Isikoff, Souter Declines Comment on Abortion: Nominee Moves to Dispel Image as Judge Lacking Compassion, WASH. PosT, Sept. 14, 1990, at A1. 
someone may seem unbiased and removed from a matter, he or she may be implicated and seem not to be because of unexamined assumptions about the baseline used to judge neutrality and impartiality.

Consider a case involving a charge of sex discrimination against a law firm. In one such case, the defendant law firm asked Judge Constance Baker Motley to recuse herself from the case because she, as a black woman who had once represented plaintiffs in discrimination cases, would identify with those who suffer race or sex discrimination. ${ }^{26}$ The defendant invoked the notion that the judge would be too close to the case. The defendant assumed that Judge Motley's personal identity and her past legal work deprived her of impartiality. Judge Motley declined to recuse herself and explained:

[I] background or sex or race of each judge were, by definition, sufficient grounds for removal, no judge on this court could hear this case, or many others, by virtue of the fact that all of them were attorneys, of a sex, often with distinguished law firm or public service backgrounds. ${ }^{27}$

Similarly, Judge Leon Higginbotham once was asked to remove himself from a race discrimination case because he is an AfricanAmerican. ${ }^{28}$ In declining, he noted that "black lawyers have litigated in the federal courts almost exclusively before white judges, yet they have not urged that white judges should be disqualified on matters of race relations." 29

Judge Motley and Judge Higginbotham may be understood to suggest that they are no more too close to the matter than judges of a different race or sex might be too far from it. Yet they both advance a different view of bias and impartiality. They mean to expose the assumption that the neutral baseline against which to evaluate bias is the vantage point of a white male. They mean to show that even whites and males have a vantage point that can and should be evaluated for bias. Departure from a white male perspective, however, does not necessarily mean bias. Judge Motley and Judge Higginbotham mean to demand a more particularized showing of bias than an assertion of sex or race,

26. Blank v. Sullivan \& Cromwell, 418 F. Supp. 1, $4-5$ (S.D.N.Y. 1975).

27. $I d$. at 4.

28. Pennsylvania v. Local Union 542, Int'l Union of Operating Eng'rs, 388 F. Supp. 155, 156-57 (E.D. Pa. 1974).

29. Id. at 177 . 
and also to remind any who need reminding that men as well as women have a sex, and whites as well as blacks have a race. These categories implicate us all. If being implicated means bias, then everyone is biased, and perhaps then no one can judge. That result is unacceptable, but it helps suggest a norm of inclusion to govern who may serve as judge or jury. It points out the danger of considering an initial appearance of bias without probing how others may be similarly but more subtly implicated in the issue of bias.

Consider a problem chosen not at random - a case arising from a charge of sexual harassment. If brought before a woman judge or before women jurors some might worry about biased decisionmakers. If the decisionmaker herself were a victim of sexual harassment, some might worry that she would be unduly inclined to believe and favor the complainant. As polls conducted during Clarence Thomas's Senate hearings demonstrate, women who have been harassed may instead be skeptical of another woman's claims. ${ }^{30}$ Perhaps the complainant did not respond the way the adjudicator did or would have; perhaps the complainant appears disloyal or otherwise blameworthy in the eyes of the adjudicator. These alternatives simply point to the multiple directions that bias may take, but not to its absence. Would restricting decisionmaking to a man or group of men be any better? Some people worried that Anita Hill's charges were not taken seriously enough by the Senate Judiciary Committee in part because the Committee was composed entirely of men who seemed not to comprehend the seriousness of the problem. ${ }^{31}$ Some argue that the presence of even just one woman Senator would have made a difference on this score. ${ }^{32}$ This is an asserted connection between notions of fair representation or cross-section and the impartiality necessary to judge the significance of a charge.

But a different line of criticism can be applied to a panel of male adjudicators of sexual harassment claims. Those adjudicators might identify with the accused and might worry about

30. Felicity Barringer, The Thomas Confirmation: Hill's Case Is Divisive to Women, N.Y. TIMES, Oct. 18, 1991, at A10.

31. See, e.g., Carol Kleiman, After Senate's Thomas-Hill Debate, Two Women Seek Entry to Men's Club, CHI. TriB., Feb. 24, 1992, at 5.

32. See $i d$. The confidence with which this point is uttered is challenged somewhat by the position of Senator Nancy Kassebaum, who voted in favor of confirming Clarence Thomas when the question reached the full Senate. Nevertheless, unlike some of her male colleagues, Senator Kassebaum also refused to be "a party to an intellectual witch hunt against Professor Hill." The Thomas Confirmation: Women in Senate Have Their Say Before the Vote Confirming Thomas, N.Y. TIMEs, Oct. 16, 1991, at A18. 
being accused themselves. They might worry about false accusations and the difficulty of rebutting them. They might worry about true accusations, yet not believe them serious enough to warrant public sanction. They also might worry about true accusations and seek to show their ability to overcome any appearance of bias by coming down hard on the accused.

I do not mean to suggest that everyone is equally or identically biased. I do mean to suggest that commonplace notions of being too close or too far from the parties or the problem at hand inadequately capture the issue of bias. Instead, people's multiple perspectives on a problem may diverge in different ways from the ideal of impartiality. For that very reason, a collaborative decisionmaking process involving people reflecting those multiple perspectives exhibits the special virtue of a jury or multijudge panel compared with a single judge. The value of consultation is enhanced not merely by the presence of more than one mind but also by the presence of more than one vantage point. ${ }^{33}$ This is another way of saying that fair representation and impartiality converge.

\section{Criticizing the SUPREme CourT}

The Supreme Court's decision last Term in Hernandez v. New York ${ }^{34}$ provides an occasion to test these comments and in turn, to test the Supreme Court. In Hernandez, the prosecution tried a case against a Latino criminal defendant and used its peremptory challenges to exclude jurors who failed to assure the prosecutor adequately that they could defer to the official English translation of any Spanish-language testimony. ${ }^{35}$ The defendant claimed that the resulting jury violated equal protection guarantees because it effectively excluded all Spanish-proficient jurors. $^{36}$

The case sharply divided the Supreme Court. ${ }^{37}$ Four Justices signed the plurality opinion in which Justice Kennedy reasoned

33. A single judge can try to engage in an imaginative dialogue with people with different vantage points on the problem at hand. $C f$. HANNAH ARENDT, BETWEEN PAST AND FUTURE: SIX ExeRcises IN PoLITICAL Thought 220-21 (1961) (suggesting that judgment derives its validity from agreement of individuals with various perspectives).

34. 111 S. Ct. 1859 (1991) (plurality opinion).

35. $I d$. at 1864-65. The prosecution also used its peremptory challenges to exclude jurors with family members who had been convicted of crimes. Id. at 1864 .

36. Id. at $1866-67$.

37. Four members of the Court signed Justice Kennedy's plurality opinion, $i d$. at 1864, 
that the prosecutor offered explanations for his challenges, explanations sufficiently unrelated to race, and that thus no intentional discrimination occurred. ${ }^{38}$ These Justices did not rely on the view that ethnicity or language proficiency are unrelated to race. They could have relied on the fact that many people who speak Spanish are not Latinos and that many Latinos do not speak Spanish, but they did not. ${ }^{39}$ Indeed, Justice Kennedy's opinion includes a rather remarkable statement about the close relationships between language and identity and between language and ethnicity, close enough at times to justify equal protection scrutiny on the basis of language proficiency..$^{40}$ To reject the defendant's claim, therefore, Justice Kennedy's opinion had to reason that a prima facie showing of an equal protection violation had been rebutted by the absence of proof that the prosecutor intended to exclude based on race..$^{41}$

The plurality argued more specifically that the prosecutor had offered a neutral explanation for the peremptory challenges: the Latino jurors raised doubts for the prosecutor when they hesitated before they answered that they would try to defer to the official English translation of Spanish testimony at the trial. ${ }^{42}$ This doubt, the plurality claimed, was unrelated to race or ethnicity. Some Latinos would give no such grounds for doubt, and some non-Latinos would. Thus, the plurality found that the exclusions were not based on race. ${ }^{43}$

But let us examine the exclusions more closely. Why would it be legitimate to worry about a juror who could not ignore testimony given by witnesses, and not therefore need to defer solely to a court translator's version? Two linked reasons might be at stake. This Spanish-proficient juror might base judgment on information unavailable to other jurors and this juror might

two members signed another opinion authored by Justice $0^{\prime}$ Connor, $i d$. at 1873, Justice Stevens wrote a dissent joined by Justice Marshall, $i d$. at 1875, and Justice Blackmun dissented separately while indicating agreement with one part of Justice Stevens's dissent, id. at 1875.

38. Id. at $1866-67$.

39. The plurality opinion did reject the defendant's claim that a close correlation between Spanish proficiency and Latino identity would be sufficient to treat exclusion of Spanish-proficient jurors as exclusions of Latinos. Yet the plurality acknowledged that, at least in this case, the exclusion of Spanish-proficient jurors had the effect of excluding virtually all Latinos. Id. at 1867 .

40. Id. at 1868.

41. Id. at 1868-69.

42. Id. at 1864-65.

43. Id. at 1867 . 
claim special knowledge and authority in the course of the jury deliberations. Why are these worrisome instead of desirable traits for a juror? These worries arise only if one supposes:

(1) that the normal juror would not know Spanish;

(2) that only the official English translation of Spanish testimony should be used in the jury's deliberations;

(3) that people who do not speak Spanish adequately can fairly judge people who do; and

(4) that the exclusion of Latinos from the jury leaves a jury that can be perceived as fair and impartial in a case involving a Latino defendant (and, in this case, Latino victims as well).

Underscoring these suppositions is Justice Kennedy's endorsement of the trial court's conclusion that, because Latino jurors might be sympathetic to both the Latino defendant and to the Latino victims and witnesses, it is not discriminatory to exclude Latino jurors; the sympathies wash out.44 This view neglects not only Latinos in the community who view trial participation as a civic right but also ignores all those troubled by the omission of an entire perspective and knowledge base from the jury. Moreover, it also wrongly implies that only Latinos have sympathies in cases involving Latinos.

Treating only Spanish-speaking Latinos as a problem, the plurality cited a case "which illustrates the sort of problems that may arise where a juror fails to accept the official translation of foreign-language testimony."45 In United States $v$. Perez, ${ }^{46}$ a juror asked the judge if it would be possible to ask the translator about the meaning of a particular term. The translator had interpreted the word to mean a public bar although the juror thought it meant a restroom. The judge indicated that questions could be put only to the judge, not to the interpreter. The interpreter nonetheless volunteered that jurors "are not to listen to the Spanish but to the English. I am a certified court interpreter." 47 At this point, the transcript produced by the court reporter indicated that the juror called the translator an "idiot."48 The juror later explained, however, that she had said, "It's an idiom." ${ }^{49}$ (We have several layers of interpretation problems here!) The juror was dismissed from the jury..$^{50}$

\footnotetext{
44. Id. at 1871-72 (deferring to the trial court's finding).

45. Id. at 1867 n.3 (citing United States v. Perez, 658 F.2d 654 (9th Cir. 1981)).

46. 658 F.2d 654 .

47. Id. at 662 .

48. Hernandez, $111 \mathrm{~S}$. Ct. at 1867.

49. Id.

50. Id.
} 
This episode, offered by Justice Kennedy as evidence of the sort of problems that may arise when a juror fails to accept the official translation of foreign-language testimony, may also indicate the sorts of problems that arise when the trial process fails to accommodate people who are bilingual. The juror's question was treated as an intrusion rather than as an effort to get at the truth; the witness's testimony, she suggested, would make more sense if it referred to a restroom rather than a bar. The court interpreter reacted defensively, and the judge responded by banishing the inquiring juror from the trial.

This story contrasts sharply with a case in which a man got into a fight in a bar with another man and killed him. ${ }^{51}$ Both men were Mexican-Americans. The offender argued that his victim had given him "el ojo," meaning, "the eye."52 At that time, no Mexican-Americans were eligible to serve on juries in Texas, where the incident occurred. ${ }^{53}$ The defendant was convicted of murder. As one observer noted about the case:
"Anglos have a big thing about eye contact being something positive. You can take a man's measure by making contact.... Hell, in the Mexican community eye contact can kill you. It sends the other guy a message that says what the hell are you lookin' at, and if you don't like it, do something about it. In a bar that can lead to a killing. But if you don't know that you can't relate to what it means. And unless jurors understand the difference between $e l$ ojo and eye contact, the defendant is not being tried by a jury of his peers." ${ }^{44}$

The Supreme Court of the United States essentially agreed. In 1954, the Supreme Court-the same Court that decided Brown v. Board of Education ${ }^{55}$ - reversed the conviction..$^{56}$ The Court was composed of Justices quite different from those serving on the present Court. The present Court has moved away from recognizing language, ethnic, and racial differences as important dimensions of American life and dimensions to be integrated throughout our institutions. Instead, the Court seems to fear differences and to desire to exclude those people it fears. Because

51. See Hernandez v. State, 251 S.W.2d 531 (Tex. Crim. App. 1952), rev'd sub nom. Hernandez v. Texas, 347 U.S. 475 (1954).

52. Thomas Weyr, Hispanic U.S.A.: Breaking the Melting Pot 83 (1988).

53. Hernandez, 251 S.W.2d at 533.

54. WeYR, supra note 52, at 83 (quoting Gilbert Pompa).

55. 347 U.S. 483 (1954).

56. Hernandez v. Texas, 347 U.S. 475 (1954). 
Spanish-speakers soon will probably become a majority in parts of California and Texas, ${ }^{57}$ these exclusions would be carried out in the name of a minority mistaken about the actual norm.

What if the Supreme' Court instead exposed for discussion the assumption that English-speaking and not bilingual jurors are the norm? Even in last year's case, a majority of the Justices, in separate opinions, considered ways to change the jury to accommodate bilingual jurors. Six of the nine Justices proposed that jurors proficient in a language used by witnesses be given an opportunity to indicate to the judge any problems they detect with the translations. ${ }^{58}$ The plurality acknowledged the "harsh paradox that one may become proficient enough in English to participate in trial," given the English-language ability requirements for federal jury service, "only to encounter disqualification because he knows a second language as well." ${ }^{59}$ Nevertheless, for these Justices, the treatment of bilingual jurors remained a marginal concern, largely relegated to footnotes. The assumption that the non-Spanish speaking juror is the impartial decisionmaker contributed to this failure. The problem of bias for juries and for judges arises not only when they are too close to or too far from those they judge but also when they fail to identify an entrenched and biased assumption about whose perspective is the norm.

The arguments for a jury that is a fair cross-section of the community only strengthen this critique. ${ }^{60}$ To be perceived as fair by the entire community, to accord all citizens a chance to serve as jurors, and to grant parties the opportunity to be heard by their peers, the jury should reflect a fair cross-section of the community. Such a cross-section is more likely to bring to bear knowledge critical to evaluating evidence, credibility, and justice in a given case.

57. See, e.g., Lily Eng \& Bob Schwartz, City's Latinos on the Grow, L.A. Trmes, Feb. 26, 1991, at B1; $c f$. Product Development Needed for Growing Hispanic Population, UPI, July 21, 1988 (noting that one in four Texans will be Hispanic by the year 2000), available in LEXIS, Nexis Library, UPI File.

58. Hernandez v. New York, 111 S. Ct. 1859, 1868 (1991) (plurality opinion); id. at 1877 (Stevens, J., dissenting).

59. Id, at 1872 .

60. Those arguments include the rights of the parties to be evaluated by a jury of their peers, the rights of potential jurors to serve, and the prerequisites for public confidence in the process of trial. See Holland v. Illinois, 493 U.S. 474, 495 (1990) (Marshall, J., dissenting). 


\section{Prejudice vs. Prior Knowledge}

In case I seem to have implied that bias and prejudice are not problems for juries and judges, let me turn to a distinction between prejudice and prior knowledge. I believe that an important distinction does exist. Prejudice interferes with impartiality. Prior knowledge may assist impartiality, however, if coupled with a willingness to be surprised, rather than always confirmed. Let me offer into evidence a short story by James Baldwin, entitled Sonny's Blues. ${ }^{61}$

It is a story of two brothers, both African-American. One brother, the narrator, served in the Army and then became a high school math teacher, a husband, and a father. His younger brother, Sonny, became a heroin addict, a convicted felon, and a jazz pianist. ${ }^{62}$ The school teacher ignored Sonny during the initial period of Sonny's incarceration. But when the teacher's daughter dies of polio, Sonny writes him a heartfelt letter. ${ }^{63}$ They then stay in touch, and when Sonny is released, they reunite. But the teacher is wary, concerned that Sonny will continue to use drugs. He simultaneously feels guilty and worries that he is not fulfilling his mother's last wish that he watch out for his brother. ${ }^{64}$ Sonny tells his brother he knows that he may start using drugs again..$^{65}$

Reluctantly, the teacher accepts Sonny's invitation to join him at a nightclub. For the first time, he hears Sonny play the piano. ${ }^{66}$ It is Sonny's first return to the instrument since his time in prison. The teacher-narrator notes: "All I know about music is that not many people ever really hear it. And even then, on the rare occasions when something opens within, and the music enters, what we mainly hear, or hear corroborated, are personal, private, vanishing evocations" different from what is evoked for the person making the music. ${ }^{67}$ Drenched with his prior knowl-

61. James Baldwin, Sonny's Blues, in How We Live: Contemporary Life IN ConteMPORARY FICTION 747 (Penney Chapin Hills \& L. Rust Hills eds., 1968).

62. Id. at 748-50, 761-62.

63. Id. at 751 .

64. His mother had said, "It ain't only the bad ones, nor yet the dumb ones that gets sucked under," " $i d$. at 756, and then she told him about his uncle who had been lynched, id. at 757. She said, "You got to hold on to your brother . . . and don't let him fall, no matter what it looks like is happening to him and no matter how evil you gets with him." "Id. at 757-58. She added, "You may not be able to stop nothing from happening. But you got to let him know you's there." "Id. at 758.

65. Id. at 768 .

66. Id. at 769 .

67. Id. at 770 . 
edge and suspicion of Sonny, and with feelings of guilt, the narrator still tries to discern what Sonny feels as he plays. $\mathrm{He}$ begins to recognize the dialogue between Sonny and the musician playing the bass fiddle. The bass player "wanted Sonny to leave the shoreline and strike out for the deep water. He was Sonny's witness that deep water and drowning were not the same thinghe had been there, and he knew."68 The narrator watches his brother move from absence to real presence with the other musicians and then join them in finding new ways to make the audience listen to the not-new story of human suffering. ${ }^{69}$ The narrator is brought to his own memories but also to a new respect for his brother, a man who chose not the norms of middleclass respectability, but expression of human experience through the blues.

The narrator is not asked to judge Sonny, although he does so. Nonetheless, the story suggests the difference between prejudging a matter, even when prejudice is based on actual knowledge, and the use of prior knowledge as part of a process of opening up to the possibility of surprise. The story suggests the difference between mulling over personal, private evocations and attending to the situation of another person. The story also suggests that, initially, the shared past and experiences of the two brothers stand as a barrier to mutual understanding. Later, however, the narrator is able to integrate his memories of his parents and his brother into a new understanding and respect for the path Sonny takes. It may be too much to suggest that we are all brothers and sisters in this way, although such an attitude need not interfere with impartiality if we try to use what we know to remain open to surprises about one another. I have used this story in teaching judges ${ }^{70}$ and often asked these questions: "If you were asked to sentence Sonny in a new drug charge, would you want to know about the piano playing? Would you want to hear it? Would you want to include as judges and juries people who know Sonny's world or only people with no knowledge of it? Is there anyone who is not implicated in it?"

Let me contrast this story with the recent movie Thelma \& Louise. $^{71}$ Two women plan a weekend away from the men in their

68. Id.

69. Id. at 771 .

70. See Martha Minow, Words and the Door to the Land of Change: Law, Language, and Family Violence, 43 VAND. L. REv. 1665, 1689-95 (1990).

71. TheLMA \& LouISE (MGM-Pathe 1991). 
lives, but they quickly find trouble at a honky-tonk. A man starts dancing with Thelma, then makes sexual advances toward her. When she resists, he violently starts to rape her. Louise appears with a gun, the man stops, but he shows no remorse, and Louise kills him. The rest of the movie follows their journey as outlaws, trying to escape legal repercussions. The movie includes their encounter with a truck driver who repeatedly makes gross sexual advances toward them and their fantasy revenge against him. The movie concludes with their suicide in a world aiming to capture and punish them, a world they do not believe could understand them.

The film triggered considerable press. In Boston, the Globe ran side-by-side columns: A woman's review was entitled, She Loves It:72 a man's review: He Hates It. $^{73}$ The Boston Globe has its own problems of perspective. A common prediction about that paper is that if a nuclear bomb fell on New York, the headline in the Boston Globe would read: "Hub Man Injured in Explosion."74 But the issue of perspective is unusually pronounced in evaluations of the movie Thelma \& Louise. Some charge the movie with stereotyping men and giving bad role models for women. Others cheer its depiction of women fighting back in a world they find unsafe and inhospitable. Perhaps only a law professor would like best a particular line in the movie. It is uttered as the two women discuss how police and prosecutors would not understand how a woman who danced with a man could establish his sexual advances were unwanted. Thelma says, "Law is some tricky shit."75 That statement summarizes the conviction that the maledominated legal system will not understand how a woman could charge rape after she flirted with a man or how a woman could be excused or forgiven for killing a man after he had stopped raping a woman. Perhaps the polarized reviews confirm their doubt. In a way, Anita Hill's experience could be described as "Thelma and Louise Meet the Supreme Court Nomination Process-and Discover How Unsafe and Inhospitable the Senate is from a Woman's Point of View."

I put the film forward here for a different reason. I wonder whether the film, like the story, Sonny's Blues, asks us to use

72. Diane White, She Loves $I t$, Boston GLoBE, June 14, 1991, at 29.

73. John Robinson, He Hates It, Boston GLOBE, June 14, 1991, at 29.

74. "Hub" is the Globe's abbreviation for Boston as the hub of the universe. See Ask the Globe, Boston GLOBE, Sept. 8, 1990, at 60.

75. Thelma \& Louise, supra note 71. 
what we know but to suspend our conclusions long enough to be surprised, to learn. One of the actresses who starred in Thelma $\&$ Louise said that people who find that the film mistreats men are identifying with the wrong characters. ${ }^{76}$ She invites all viewers to identify with the journey of self-discovery and self-criticism undertaken by Thelma and Louise. They know they have done something wrong, and the film does not excuse them. But it invites understanding and wagers that gender is no obstacle to that. None of us can know anything except by building upon, challenging, responding to what we already have known, what we see from where we stand. But we can insist on seeing what we are used to seeing, or else we can try to see something new and fresh. The latter is the open mind we hope for from those who judge, but not the mind as a sieve without prior reference points and commitments. We want judges and juries to be objective about the facts and the questions of guilt and innocence but committed to building upon what they already know about the world, human beings, and each person's own implication in the lives of others. Pretending not to know risks leaving unexamined the very assumptions that deserve reconsideration.

\section{Prejudice, Prior Knowledge, and the Supreme Court}

This prompts me, once more, to consider the situation of Justice Clarence Thomas, both as judge and as someone to be judged. Three versions of what has happened to him have emerged:

(1) The Republican story, put most cogently by the nominee himself, of a high-tech lynching, a process spun out of control through the manipulations of liberal interest groups, Senate staff members, and ambitious press people who conspired to produce a charge of sexual harassment, delay its evaluation, leak it at the eleventh hour, and prompt a circus-like hearing besmirching Thomas's good name.

(2) The Democratic story of a terrible process, but one with no better alternative, because the Constitution calls upon the Senate to advise and consent to presidential nominations, because the complainant's demand for confidentiality delayed consideration of the charge of harassment, and because an unfortunate leak to the press brought to public attention this serious charge and required public resolution.

76. See Judith Michaelson, Doumright Serious: With "Thelma \& Louise," Geena Davis Is Forging a New Image, Closer to Her Own Reality of a Woman Who Takes Care of Her Life, L.A. Trmes, May 12, 1991, at 5 (quoting Geena Davis). 
(3) The baptism-by-fire theory, according to which we have witnessed a process of intensive job training, with the result that Clarence Thomas may end up emphatically defending privacy, and the rights of the accused. He criticized racial stereotypes and concluded that his own integrity mattered more than ambition - in contrast to positions he had taken previously.

I want to believe the third story, and Thomas himself has testified to it. ${ }^{77}$ But he has also indicated his fury at the Senate, his disdain for liberal interest groups and, it seems, apparent disrespect for many Democrats and press people. ${ }^{78}$ To some observers, he seems untrustworthy on questions of sexual harassment, perhaps even a lying perpetrator.

Will Thomas now recuse himself from cases of sexual harassment? From cases involving liberal interests groups or Democratic Senators? These matters will remain with his conscience. To be fair, we should not use our metaphoric peremptory challenges against him. But to earn the respect of the public, he must indicate how he will draw on the parts of his past that he claimed taught him about people left out, disadvantaged, and misunderstood. It would help if he worked to prompt other Justices to make explicit the assumptions they take for granted about whose perspective is neutral and whose is biased. It would help if he does not strip himself down like a runner, but instead acknowledges his own situation as a brother ${ }^{79}$ implicated in the lives of others and able to be surprised while he builds upon what he already knows.

77. See Neil A. Lewis, The Thomas Swearing-In: After Ordeal of Senate Confirmation, Views on Thomas's Court Opinions, N.Y. Trmes, Oct. 19, 1991, at 8.

78. See Peter G. Gosselin, Thomas Says He'll Fight to the End, Boston GLOBE, Oct. 13, 1991, at 1.

79. Thomas's treatment of his sister in a speech commenting on her dependency on Aid to Families with Dependent Children gave some critics another ground for attack, because he seemed to register callous disregard for her difficult times, ignorance about the gender difference that had contributed to their contrasting life stories, and recklessness with the truth. See Joel F. Handler, The Judge and His Sister: Growing up Black, N.Y. Times, July 23, 1991, at A20 (letter to the Editor). 